\title{
Genetic gains in the UENF-14 popcorn population with recurrent selection
}

\author{
I.L.J. Freitas ${ }^{1}$, A.T. do Amaral Júnior ${ }^{1}$, S.P. Freitas Jr. ${ }^{2}$, P.D.S. Cabral', \\ R.M. Ribeiro ${ }^{1}$ and L.S.A. Gonçalves ${ }^{3}$
}

${ }^{1}$ Universidade Estadual do Norte Fluminense Darcy Ribeiro, Campos dos Goytacazes, RJ, Brasil

${ }^{2}$ Universidade Federal do Ceará, Campus do Cariri, Cariri, CE, Brasil

${ }^{3}$ Universidade Estudual de Maringá, Maringá, PR, Brasil

Corresponding author: I.L.J. Freitas

E-mail: ismaelljf@yahoo.com.br

Genet. Mol. Res. 13 (1): 518-527 (2014)

Received August 27, 2013

Accepted October 28, 2013

Published January 21, 2014

DOI http://dx.doi.org/10.4238/2014.January.21.21

\begin{abstract}
The popcorn breeding program of Universidade Estadual do Norte Fluminense Darcy Ribeiro aims to provide farmers a cultivar with desirable agronomic traits, particularly with respect to grain yield (GY) and popping expansion (PE). We evaluated full-sib families from the seventh cycle of recurrent selection and estimated the genetic progress with respect to GY and PE. Eight traits were evaluated in 200 full-sib families that were randomized into blocks with two replicates per set in two contrasting environments, Campos dos Goytacazes and Itaocara, located in north and northwest Rio de Janeiro State, respectively. There were significant differences between sets in families with respect to all traits evaluated, which indicates genetic variability that may be explored in future cycles. Using random economic weights in the selection of superior progenies, the Mulamba and Mock index showed gains for PE and GY of 5.11 and $7.78 \%$, respectively. Significant $\mathrm{PE}$ and GY increases were found when comparing the evolution of mean values of these two parameters that were assessed at cycles $\mathrm{C}_{0}-\mathrm{C}_{6}$ and predicted for $\mathrm{C}_{7}$. Thus, an advanced-cycle popcorn cultivar with
\end{abstract}


genotypic superiority for the main traits of economic interest can be made available to farmers in Rio de Janeiro State.

Key words: Zea mays; Genetic improvement; Selection index; Recurrent selection

\section{INTRODUCTION}

Among so-called "special corns", popcorn is a high-yield crop and has had a particularly positive impact on Brazilian economic sectors. Its final product has widespread popular acceptance and significantly drives the informal economy. There has been a steady increase in the production and consumption of popcorn as a result of the improvement and popularization of electric devices and microwave ovens for popping, and popcorn enjoys a presence in diverse food sector businesses in large and small towns across the country (Moterle et al., 2011; Pena et al., 2012; Ribeiro et al., 2012; Vittorazzi et al., 2013).

The popcorn crop yield in the recent past has been modest and imports were required from the United States and Argentina (in particular) to meet demand in Brazil (Freitas Júnior et al., 2009b). However, there have been changes in the market, and grain imports have been greatly reduced with large-scale use of Brazilian and American hybrids (Rangel et al., 2008).

The mean price of a $30-\mathrm{kg}$ bag of popcorn in 2011 was $\mathrm{R} \$ 42.60$, which was more than double the price of common corn, whose cost per $60-\mathrm{kg}$ bag was $\mathrm{R} \$ 40.00$, according to data from Agrianual (2012). Nevertheless, there is a lack of popcorn cultivars on the cereal market with desirable agronomic traits, which means that the release of commercial varieties and hybrids must be enhanced (Rangel et al., 2011).

Recurrent selection, the most widely strategy used in population breeding programs worldwide, aims to gradually increase the frequency of alleles favorable for traits of interest through repeated selection cycles and does not reduce the population's genetic variability (Hallauer and Carena, 2009; Freitas Júnior et al., 2009b; Hallauer et al., 2010). This is a key strategy for recommending varieties, and it has been shown to be effective in providing genetic gains with respect to the primary traits of popcorn (Amaral Júnior et al., 2010).

The only breeding program for the crop in the State of Rio de Janeiro was developed by Universidade Estadual do Norte Fluminense Darcy Ribeiro (State University of Norte Fluminense "Darcy Ribeiro", UENF), which was established in 1998 (Pereira and Amaral Júnior, 2001). This program works in collaboration with researchers in Brazil, including those at EMBRAPA - Milho e Sorgo (Brazilian Agricultural Research Corporation - Maize and Sorghum), Universidade Estadual de Maringá (Maringá State University, UEM), and Universidade Federal de Viçosa (Federal University of Viçosa, UFV), in Mexico at CIMMYT (International Maize and Wheat Improvement Center), and in the United States at North Dakota State University. One of the program's aims is to provide popcorn cultivars with desirable agronomic traits-particularly with respect to grain yield (GY) and popping expansion (PE) - to farmers in the North Fluminense Region and the Northwest Fluminense Region (Ribeiro et al., 2012; Silva et al., 2013).

Following the implementation of six cycles of recurrent selection in the UNB-2U population, which is now designated UENF-14, significant increases have been obtained in the primary economically important crop traits. There was an increase from 19.25 to 31.13 
$\mathrm{mL} / \mathrm{g}$ in PE and from 1.699.44 to $2.987 .84 \mathrm{~kg} / \mathrm{ha}$ in GY (Rangel et al., 2008; Freitas Júnior et al., 2009b; Ribeiro et al., 2012); these values are consistent with those recommended for the release of superior material (Pena et al., 2012).

This study was implemented to continue the recurrent selection program of UENF by evaluating full-sib families from the seventh selection cycle and to estimate genetic progress with respect to GY and PE.

\section{MATERIAL AND METHODS}

\section{UENF-14 population origin}

The open-pollinated UENF-14 variety refers to cycle $\mathrm{C}_{6}$ of the recurrent selection of UNB-2U. UNB-2U, in turn, stemmed from two cycles of mass selection of UNB-2, at Campos dos Goytacazes, RJ. The UNB-2 population derived from a selection of an indigenous compound donated to Universidade de Brasília, Brasília (University of Brasília, UNB), DF by Escola Superior de Agricultura "Luiz de Queiroz" of Universidade de São Paulo (ESALQ/ USP). The UNB-1 population was prepared using this procedure and crossed with an American popcorn variety. The progeny of this cross was selected and crossed with a yellow-grain popcorn variety resistant to Exserohilum turcicum (spot blotch). The population resulting from these two cycles of mass selection showed resistance, higher yield, and yellow grains. The open-pollinated UNB-2U population was obtained after three backcrosses with the American variety (Pereira and Amaral Júnior, 2001).

\section{Experimental environments}

The experiments were conducted in two different environments. The first was located at Colégio Estadual Agrícola Antônio Sarlo in the municipality of Campos dos Goytacazes, in the North Region of the State of Rio de Janeiro. The regional climate is classified as tropical wet, with an average annual rainfall of $1023 \mathrm{~mm}$, potential evapotranspiration of $1601 \mathrm{~mm}$ and an average annual temperature of $23^{\circ} \mathrm{C}$. The second environment was located at Empresa de Pesquisa Agropecuária do Estado do Rio de Janeiro (PESAGRO-Rio) Agricultural Experiment Station, in Ilha do Pomba, Itaocara, Rio de Janeiro, at the Northwest Fluminense Region at an altitude of $60 \mathrm{~m}$, with an average annual temperature of $22.5^{\circ} \mathrm{C}$ and average annual rainfall of $1041 \mathrm{~mm}$. The two locations are $110 \mathrm{~km}$ apart.

\section{Crop breeding and management}

Recurrent selection among full-sib families was the method employed. A total of 300 lines consisting of a mixture of seeds recombined from the sixth cycle of recurrent selection of UENF-14 were sown at Colégio Estadual Agrícola Antônio Sarlo to originate full-sib progeny. The spacing consisted of 5.00-m furrows, spaced $0.90 \mathrm{~m}$ apart, with 25 plants $0.20 \mathrm{~m}$ apart in each furrow; three seeds were used per hole at a depth of $0.05 \mathrm{~m}$. Thinning was performed 21 days after emergence, leaving one plant per hole.

At planting, fertilization was performed with $350 \mathrm{~kg} / \mathrm{ha} \mathrm{N}-\mathrm{P}-\mathrm{K}$ using a 4-14-8 formulation, and top-dressing fertilization was performed 30 days after emergence using $60 \mathrm{~kg} / \mathrm{ha}$ 
nitrogen in the form of ammonium sulfate. Crop management was performed when necessary, consistent with the recommendations for the crop (Silva et al., 2013).

\section{Evaluation and selection of progeny in competition assays}

The populations UENF-14- $\mathrm{C}_{0}$, UENF-14-C ${ }_{1}$, UENF-14-C $\mathrm{C}_{2}$, UENF-14- $\mathrm{C}_{3}$, UENF14- $\mathrm{C}_{4}$, UENF-14-C $\mathrm{C}_{5}$, UENF-14-C , $_{6}$, and the modified single-cross hybrid IAC-112 were included in the evaluation of 200 full-sib families for the purpose of comparison. The experiments were conducted in October 2011 in Itaocara (PESAGRO-Rio Agricultural Experiment Station, Ilha do Pomba) and Campos dos Goytacazes (Colégio Estadual Agrícola Antônio Sarlo) in a randomized block design with replicates in the sets. Eight sets with two replicates were used, and each set contained 33 treatments, i.e., 25 full-sib families and eight controls. The inclusion of control populations aimed to evaluate the cycles of the UENF-14 population comparatively.

The spacing used consisted of $5.00-\mathrm{m}$ furrows $0.90 \mathrm{~m}$ apart, with 25 plants $0.20 \mathrm{~m}$ from one another. Three seeds were sown in each hole at a depth of $0.05 \mathrm{~m}$, and thinning was performed 21 days after emergence, which left one plant per hole, which formed a population of 55,555 plants per hectare. Fertilization at planting was performed according to soil analysis. Top-dressing fertilization was performed 30 days after sowing. Crop management was performed according to crop needs.

The following traits were evaluated: mean plant height $(\mathrm{PH})$ in $\mathrm{cm}$; mean first ear height (FEH) in cm; final stand (FS), which was expressed as the mean number of plants per furrow; lodging (Lodg.), expressed as the number of lodged and broken plants; stalk diameter in $\mathrm{mm}$; prolificacy, which refers to the average number of ears per plant; GY in $\mathrm{kg} / \mathrm{ha}$, and $\mathrm{PE}$ in $\mathrm{mL} / \mathrm{g}$.

\section{Statistical analysis}

The analysis of variance of the data from the evaluated traits was performed according to the statistical model $\mathrm{Y}_{\mathrm{ijkl}}=\mu+\mathrm{A}_{\mathrm{i}}+\mathrm{S}_{\mathrm{j}}+\mathrm{ES}_{\mathrm{ij}}+\mathrm{R} / \mathrm{ES}_{\mathrm{ijk}}+\mathrm{F} / \mathrm{S}_{\mathrm{j} 1}+\mathrm{EF} / \mathrm{S}_{\mathrm{ijj}}+\xi_{\mathrm{ijk} l}$, where $\mu$ is the mean, $A_{i}$ is the fixed effect of the $\mathrm{i}^{\text {th }}$ environment, $S_{j}$ is the effect of the $\mathrm{j}^{\text {th }}$ set, $E S_{i j}$ is the effect of the interaction between environments and sets, $R / E S_{i j k}$ is the effect of the $\mathrm{k}^{\text {th }}$ replicate per interaction between the $\mathrm{i}^{\text {th }}$ environment and $\mathrm{j}^{\text {th }}$ set, $F / S_{j l}$ is the random effect of the $\mathrm{i}^{\text {th }}$ genotype within the $\mathrm{j}^{\text {th }}$ set, $E F / S_{i j l}$ is the effect of the interaction between genotypes and environments for the $\mathrm{j}^{\text {th }}$ set, and $\xi_{\mathrm{ijkl}}$ is the experimental error.

The data with respect to the traits were used in the analysis of variance on the basis of the proposed model, using the SAS ${ }^{\circledR}$ software (SAS 9.1, SAS Institute, Cary, NC, USA).

\section{Genetic, phenotypic and environmental components}

$\sigma_{g}^{2}=\frac{Q M F / S-Q M R}{e r}$ is the estimator of genotypic variance among families; $\sigma_{p}^{2}=\frac{Q M F / s}{e r}$ is the estimator of phenotypic variance among families; $h_{x}^{2}=\frac{\sigma_{g}^{2}}{\sigma_{p}^{2}}=\frac{Q M P / S-Q M R}{Q M P / S}$ is the heritability based on the average of families; and $I_{V}=\frac{C V g}{c v e}$ is the variation index estimator.

\section{Mulamba and Mock selection index (1978)}

The genotypic standard deviation, genotypic coefficient of variation, variation index, her- 
itability estimate, and trial-based weights were used as economic weights in the selection index.

The selection of superior progeny based on selection indices was conducted using the computational resources of the Genes program (Cruz, 2006).

This index consisted of classifying full-sib families according to each of the eight traits evaluated, in an order that is conducive to improvement. This classification results in an additional measure that is used as a selection index, which is assessed by the sum of the orders of each family with respect to each trait (Cruz et al., 2012).

\section{RESULTS AND DISCUSSION}

Significant differences were found by an analysis of variance using the F-test at 1 and 5\% probability levels for all traits evaluated with respect to the source of variation 'Environment' (Table 1). That significant difference indicated that environments were different because they promoted differences in the traits evaluated. These results corroborate those of Ribeiro et al. (2012) and Silva et al. (2013), who also demonstrated the representativeness of Campos dos Goytacazes and Itaocara municipalities, in the North Fluminense Region and the Northwest Fluminense Region, respectively, as the locations for evaluating the progeny under recurrent selection.

\begin{tabular}{|c|c|c|c|c|c|c|c|c|c|}
\hline \multirow[t]{2}{*}{ Source of variation } & \multirow[t]{2}{*}{ d.f. } & \multicolumn{8}{|c|}{ Mean squares } \\
\hline & & $\mathrm{PH}$ & FEH & FS & Lodg. & Diam. & Prolif. & GY & $\mathrm{PE}$ \\
\hline Environment (E) & 1 & $23.748^{* *}$ & $9.841^{* *}$ & $922.932 * *$ & $323.318^{* *}$ & $13.369011^{*}$ & $8.663 * *$ & $5318672.6^{*}$ & $165.358^{*}$ \\
\hline Set (S) & 7 & $0.119^{* *}$ & $0.067^{* *}$ & $72.136^{* *}$ & $2.795^{*}$ & $19.070^{* *}$ & $0.357^{* *}$ & $6071481.4 * *$ & $68.942 * *$ \\
\hline $\mathrm{E} \times \mathrm{S}$ & 7 & $0.056^{\mathrm{ns} .}$ & $0.053 * *$ & $21.736^{\mathrm{ns} .}$ & $1.792 *$ & $34.738^{* *}$ & $0.216^{* *}$ & $2706166.5^{* *}$ & $1.072^{\text {ns. }}$ \\
\hline Repl. (R) / E X S & 16 & $0.266^{* *}$ & $0.212 * *$ & $35.379^{*}$ & $16.999^{* *}$ & $63.713^{* *}$ & $0.298 * *$ & $8727955.9^{* *}$ & $4.826^{\mathrm{ns} .}$ \\
\hline Family (F) / S & 256 & $0.040^{* *}$ & $0.021 * *$ & $13.933^{*}$ & $0.862^{* *}$ & $3.622 * *$ & $0.076^{* *}$ & $1037918.3 * *$ & $41.747^{* *}$ \\
\hline $\mathrm{E} \times \mathrm{F} / \mathrm{S}$ & 256 & $0.019^{\mathrm{ns}}$ & $0.011^{*}$ & $11.068^{\mathrm{ns}}$ & $0.674^{\mathrm{ns}}$ & $2.365^{\mathrm{ns}}$ & $0.048^{\mathrm{ns}}$ & $691643.2^{* * *}$ & $12.621^{\mathrm{ns}}$ \\
\hline Error & 512 & 0.016 & 0.007 & 12.064 & 0.593 & 2.196 & 0.046 & 562523.2 & 12.207 \\
\hline Mean & & 1.99 & 1.070 & 23.602 & 2.690 & 14.483 & 1.411 & 3074.782 & 32.68 \\
\hline \multicolumn{10}{|l|}{ Genetic parameters } \\
\hline$\sigma_{g}^{2}$ & - & 0.0058 & 0.0034 & 0.4671 & 0.0672 & 0.3563 & 0.0074 & 118848.77 & 7.3847 \\
\hline$\sigma_{f}^{2^{g}}$ & - & 0.0101 & 0.0053 & 3.4831 & 0.2155 & 0.9056 & 0.0191 & 259479.6 & 10.437 \\
\hline $\mathrm{CV}_{\mathrm{e}}$ & - & 6.4800 & 8.1940 & 14.716 & 28.635 & 10.233 & 15.295 & 24.39200 & 10.689 \\
\hline $\mathrm{CV}_{\mathrm{g}}^{\mathrm{a}}$ & - & 3.8463 & 5.4347 & 2.8959 & 9.6338 & 4.1218 & 6.1088 & 11.21201 & 8.3144 \\
\hline$I(\%)$ & - & 0.5934 & 0.6631 & 0.1967 & 0.33643 & 0.4027 & 0.3993 & 0.459650 & 0.7778 \\
\hline$h_{x}^{2}$ & - & 58.478 & 63.759 & 13.413 & 31.1643 & 39.356 & 38.947 & 45.80275 & 70.758 \\
\hline
\end{tabular}

$\mathrm{PH}=$ mean plant height in cm; FEH = mean first ear height in cm; FS = final stand; Lodg. = lodging; Diam. = stalk diameter in $\mathrm{mm}$; Prolif. = prolificacy; $\mathrm{GY}=$ grain yield in $\mathrm{kg} / \mathrm{ha} ; \mathrm{PE}=$ popping expansion in $\mathrm{mL} / \mathrm{g} ; \sigma_{\mathrm{g}}^{2}=$ genotypic variance; $\sigma_{p}^{2}=$ phenotypic variance; $\mathrm{CV}_{\mathrm{e}}=$ coefficient of experimental variation; $\mathrm{CV}_{\mathrm{g}}=$ coefficient of genetic variation; $\mathrm{I}_{\mathrm{v}}^{\mathrm{p}}=$ index of variation, and $\mathrm{h}_{x f}{ }_{x f}^{\mathrm{e}}=$ heritability on the basis of families. d.f. $=$ degrees of freedom; $\mathrm{ns}=$ nonsignificant, $* \mathrm{P} \leq 0.05, * * \mathrm{P} \leq 0.01$.

With respect to the source of variation 'Set', the mean squares were significant at $1 \%$ for all traits except Lodg., which was significant at the 5\% probability level (Table 1). The significance of the traits evaluated showed the importance of using a randomized block design with treatments arranged in sets, because the absence of this source of variation could produce variations that would result in loss of experimental accuracy (Rangel et al., 2011). 
Table 1 also shows the lack of significance for PH, FS, and PE with respect to the interaction 'Environment versus Set'. The other traits were significant at the 1 or $5 \%$ probability level, which corroborates the results from Santos et al. (2007), Freitas Júnior et al. (2009b), Rangel et al. (2011), and Ribeiro et al. (2012), confirming that families were randomly distributed into sets and exhibited phenotypic changes driven by climate and soil changes in the environment.

The source of variation 'Families within the Set' $(\mathrm{F} / \mathrm{S})$, enabled the finding that most traits evaluated were significant for that source of variation at the $1 \%$ level (except for PN, which was significant at the $5 \%$ probability level), which demonstrated the existence of genetic variability to be explored in future cycles and consequent progress in the selection. The implementation of the seventh cycle of recurrent selection among full-sib families in the UENF-14 popcorn population succeeded in maintaining genetic variability. In this context, Santos et al. (2008), Freitas Júnior et al. (2009b), Rangel et al. (2011), and Ribeiro et al. (2012) showed that the goal of promoting successive gains in the UENF-14 population without losing genetic variability could be reached.

The source of variation of 'Environment versus Families within the Set' was significant at the $1 \%$ probability level regarding GY, whereas significance was detected for FEH at $5 \%$. No significance was found for the other traits at either the 5 or $1 \%$ probability level.

Knowledge of genetic parameter estimates enables the breeder to generate useful data regarding the different traits evaluated in the study population and to thereby help to guide the project towards the most appropriate selection strategy and success prediction in breeding programs (Cruz and Carneiro, 2006; Cruz et al., 2012). The analysis of Table 1 enables the identification of superior genotypes with respect to the traits of greater economic interest - GY and PE - because they showed wide genotypic variance $\left(\sigma_{g}^{2}\right)$, with estimates of $118,848.77$ for GY and 7.3847 for PE; they also showed high heritability values $\left(h_{x}^{2}\right)$, with percentages of 45.80 and $70.76 \%$ for GY and PE, respectively. Simple selection methods suffice to reach satisfactory gains regarding these traits. That superiority of heritability of PE over GY was expected, which corroborates the results found by Pereira and Amaral Júnior (2001), using the Design I in the base population (UENF-14-C C $_{0}$, by Santos et al. (2007), studying the third cycle of recurrent selection of half-sib families (UENF-14-C C $_{3}$ ), and by Freitas Júnior et al. (2009b), Rangel et al. (2011), and Ribeiro et al. (2012), studying the $\mathrm{C}_{4}, \mathrm{C}_{5}$, and $\mathrm{C}_{6}$ cycles of recurrent selection of full-sib families, respectively.

The genetic coefficient of variation $\left(\mathrm{CV}_{\mathrm{g}}\right)$ estimates provide information to the breeder about the relative magnitude of changes that may result from selection during a breeding program (Freitas Júnior et al., 2009a). Table 1 shows that, in general, traits show high $\mathrm{CV}_{\mathrm{g}}$ values, particularly Lodg., GY, and PE, which indicates a good chance of success in breeding programs using that population to select those traits. Freitas Júnior et al. (2009a), Rangel et al. (2011), and Ribeiro et al. (2012) also found high $\mathrm{CV}_{\mathrm{g}}$ values for PE and GY, the main economic traits, when studying the UENF-14 popcorn population.

With respect to the FS trait, the genetic progress using simple genetic breeding methods are not promising, which is shown by the low estimate (with a value of 0.1967) and the low magnitude of heritability (Table 2). Such fact demonstrates the importance of using recurrent selection as the breeding method. 
Table 2. Estimates of percentage gains for different selection indices and economic weights in eight characteristics assessed in 200 full-sib families in the seventh cycle of recurrent selection population UENF-14 popcorn (Campos dos Goytacazes and Itaocara, RJ, 2012).

\begin{tabular}{lccccc}
\hline Trait & \multicolumn{4}{c}{ Mulamba e Mock $^{1}$} & $\mathrm{~h}^{2}$ \\
\cline { 2 - 6 } & $\mathrm{SD}_{\mathrm{g}}$ & $\mathrm{CV}_{\mathrm{g}}$ & $\mathrm{I}_{\mathrm{v}}$ & 4.63 & $\mathrm{WAA}$ \\
\hline PH & 2.27 & 3.29 & 4.55 & 6.49 & 0.66 \\
FEH & 3.28 & 4.41 & 6.7 & 0.53 & 0.32 \\
FS & 1.24 & 0.62 & 0.82 & 0.16 & -1.04 \\
Lodg. & -1.71 & 4.38 & 0.49 & 3.69 & 1.37 \\
Diam. & 1.54 & 2.8 & 3.56 & 4.55 & 3.24 \\
Prolif. & 2.65 & 4.53 & 4.64 & 9.84 & 7.78 \\
GY & 16.02 & 10.58 & 10.18 & 2.28 & 5.11 \\
PE & -1.68 & 2.24 & 1.94 & & \\
\hline
\end{tabular}

Economic weights used for the selection index: $\mathrm{SD}_{\mathrm{g}}=$ genotypic standard deviation; $\mathrm{CV}_{\mathrm{g}}=$ coefficient of genetic variation; $I_{v}=$ index of variation; $h^{2}=$ heritability on the basis of families, and WAA = weights assigned by attempts $(14,14,2.5,2.5,2.5,20,35,40)$. For other abbreviations, see legend to table 1 .

Table 2 shows the estimates of percentage gains according to the Mulamba and Mock index (1978), using different economic weights for the eight traits evaluated. The Mulamba and Mock index (1978) has shown good results in the breeding program of UENF popcorn and is a key tool assisting the selection process (Ribeiro et al., 2012).

The values enabling the best results were found after sixty attempts of assigning economic weights because they provided the best percentage gains in the set of traits evaluated (Table 2); these values are 14, 14, 2.5, 2.5, 20,35, and 40. The estimated percentage gains for GY and PE were 7.78 and 5.11\%, respectively, which are the traits of greatest economic importance for popcorn (Table 2).

The percentage gain with respect to the number of lodged and broken plants was $-1.37 \%$ (Table 2), whose negative magnitude is useful in the selection of the most lodgingresistant plants given the strong winds that blow in the North Fluminense Region and Northwest Fluminense Region.

The use of the genotypic standard deviation $\left(\mathrm{SD}_{\mathrm{g}}\right)$ to compare the economic weights provided the largest percentage gains with respect to grain yield, with an estimate of $16.02 \%$. However, the percentage gain of $\mathrm{PE}$ using the $\mathrm{SD}_{\mathrm{g}}$ was $-1.68 \%$, whose negative estimate is undesirable. Furthermore, undesirable gains were also found for PH and FEH; in this case, they were positive and greater than those found using arbitrary weights, which favors higher plant and FEH and, therefore, Lodg.

The use of $\mathrm{CV}_{\mathrm{g}}, \mathrm{I}_{\mathrm{v}}$ and $\mathrm{h}^{2}$ as economic weights provided the highest gain estimates for PH and FEH, which most likely caused the positive gains for Lodg, not a good alternative for the popcorn breeding program at UENF. Furthermore, these economic weights resulted in the lowest positive percentage estimates of selection gains for PE (Table 2).

The trial-based economic weights conclusively provided the best-distributed gains in all traits evaluated, and the Mulamba and Mock index (1978) efficiently estimated the predicted percentage gains.

The Mulamba and Mock index (1978) also provided the best predicted gains for the third cycle of recurrent selection in the UENF-14 population conducted by Santos et al. (2007), with estimates of 10.00 and $7.16 \%$ for GY and PE, respectively. Freitas Júnior et al. (2009a) determined gains of $8.50 \%$ for GY and $10.55 \%$ for PE with respect to the 
fourth cycle of recurrent selection, also using the Mulamba and Mock index (1978). Rangel et al. (2011) concluded that the abovementioned index showed the largest predicted gains for PE and GY (8.53 and 6.01\%, respectively) in the UENF-14 cycle $\mathrm{C}_{5}$ evaluation. Ribeiro et al. (2012) estimated the highest gains for PE and GY (10.97 and 15.30\%, respectively) in performing the sixth cycle of recurrent selection of UENF-14 with the Mulamba and Mock index (1978).

Arnhold and Viana (2007) were also successful using the Mulamba and Mock index (1978) for selection between and within $\mathrm{S}_{4}$ families from the Beija-Flor popcorn population. When combined with the results found by Santos et al. (2007), Freitas Júnior et al. (2009b), Amaral Júnior et al. (2010), Rangel et al. (2011), and Ribeiro et al. (2012) in the UENF-14 population, these results show the efficiency of the Mulamba and Mock index (1978) in selecting superior progeny in popcorn breeding programs.

There was a noticeable steady increase in both PE and GY, as shown in Table 3, when the evolution of the means found for both parameters were compared in cycles $\mathrm{C}_{0}$, $\mathrm{C}_{1}, \mathrm{C}_{2}, \mathrm{C}_{3}, \mathrm{C}_{4}, \mathrm{C}_{5}$, and $\mathrm{C}_{6}$ and predicted for $\mathrm{C}_{7}$. This steady increase was also found by Freitas Júnior et al. (2009a) for cycle $\mathrm{C}_{4}$, in which the $\mathrm{GY}$ and $\mathrm{PE}$ gains continued growing even with the change in strategy from half-sib families in $\mathrm{C}_{3}$ to full-sib families in $\mathrm{C}_{4}$. Similar results were found by Santos et al. (2007), who reported that the PE gains and the increase in GY remained satisfactory with the change in selection strategy from inbred families $\left(\mathrm{S}_{1}\right)$ performed by Daros et al. (2004) to selection among half-sib families (Santos et al., 2007). Ribeiro et al. (2012) also found a gradual increase in gains of PE and GY, compared to previous cycles when performing the sixth cycle of recurrent selection of the UENF-14 population.

Table 3. Estimates of average popping expansion $(\mathrm{PE}, \mathrm{mL} / \mathrm{g})$ and grain yield $(\mathrm{GY}, \mathrm{kg} / \mathrm{ha})$ obtained for the cycles $\mathrm{C}_{0}, \mathrm{C}_{1}, \mathrm{C}_{2}, \mathrm{C}_{3}, \mathrm{C}_{4}, \mathrm{C}_{5}, \mathrm{C}_{6}$, and $\mathrm{C}_{7}$ predicted in the population UENF-14 underwent intrapopulation recurrent selection witness besides IAC-112 (Campos dos Goytacazes and Itaocara, 2012).

\begin{tabular}{llcc}
\hline Cycle & Strategy selection & GY $(\mathrm{kg} / \mathrm{ha})$ & $\mathrm{PE}(\mathrm{mL} / \mathrm{g})$ \\
\hline $\mathrm{C}_{0}$ & Individual selection & 1941.67 & 25.06 \\
$\mathrm{C}_{1}$ & Full-sib & 2264.24 & 29.02 \\
$\mathrm{C}_{2}$ & $\mathrm{~S}_{1}$ & 2679.73 & 29.15 \\
$\mathrm{C}_{3}$ & Half-sib & 2769.66 & 29.46 \\
$\mathrm{C}_{4}$ & Full-sib & 3043.27 & 29.73 \\
$\mathrm{C}_{5}$ & Full-sib & 3073.93 & 32.27 \\
$\mathrm{C}_{6}$ & Full-sib & 3100.69 & 33.82 \\
$\mathrm{C}_{7}$ & Full-sib & 3503.20 & 35.73 \\
Witness & Genetic structure & $\mathrm{GY}(\mathrm{kg} / \mathrm{ha})$ & $\mathrm{PE}(\mathrm{mL} / \mathrm{g})$ \\
IAC-112 & Modified single-cross hybrid & 3082.27 & 31.32 \\
\hline
\end{tabular}

$\mathrm{GY}=$ grain yield in $\mathrm{kg}_{\mathrm{H}} \cdot \mathrm{ha}^{-1} ; \mathrm{PE}=$ popping expansion in $\mathrm{mL} \cdot \mathrm{g}^{-1}$.

The discrepancies between the levels of recurrent selection gains for GY considering different strategies of progeny selection shown in Figure 1 are notable. The most marked differences were observed between the cycles $\mathrm{C}_{0}$ and $\mathrm{C}_{1}$ (mass selection versus full-sib), $\mathrm{C}_{1}$ and $\mathrm{C}_{2}$ (full-sib versus inbred $\mathrm{S}_{1}$ families), and $\mathrm{C}_{3}$ and $\mathrm{C}_{4}$ (half-sib versus full-sib). This corroborates the highest gain predictions for full-sib and $\mathrm{S}_{1}$ families - which is in contrast to the possible gains upon selection among half-sib families - and the mass and stratified mass selections, which were estimated by Pereira and Amaral Júnior (2001) in the early establishment of the popcorn breeding program at UENF. 


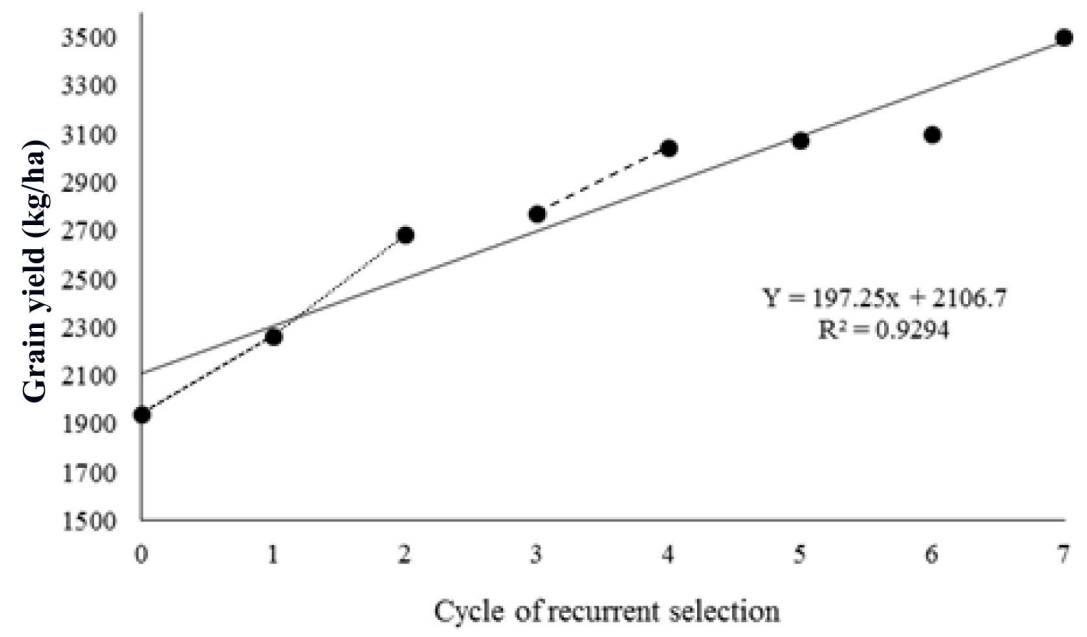

Figure 1. Evolution of the means obtained in the cycles $\mathrm{C}_{0}, \mathrm{C}_{1}, \mathrm{C}_{2}, \mathrm{C}_{3}, \mathrm{C}_{4}, \mathrm{C}_{5}, \mathrm{C}_{6}$, and predicted in $\mathrm{C}_{7}$ for the traits grain yield $(\mathrm{kg} / \mathrm{ha})$.

Table 3 also shows that the gains found in cycle $\mathrm{C}_{6}(3100.69 \mathrm{~kg} / \mathrm{ha}$ for $\mathrm{GY}$ and 33.82 $\mathrm{mL} / \mathrm{g}$ for PE) and those predicted for cycle $\mathrm{C}_{7}(3503.20 \mathrm{~kg} / \mathrm{ha}$ for $\mathrm{GY}$ and $35.73 \mathrm{~mL} / \mathrm{g}$ for $\mathrm{PE})$ were higher than in the control, which was the modified single-cross hybrid IAC-112, a cultivar previously launched in the market by IAC with a GY of $3082.27 \mathrm{~kg} / \mathrm{ha}$ and PE of $31.32 \mathrm{~mL} / \mathrm{g}$. These results corroborate those found by Silva et al. (2013), who evaluated three cycles $\left(\mathrm{C}_{3}, \mathrm{C}_{4}\right.$ and $\left.\mathrm{C}_{5}\right)$ in the UENF-14 population, in addition to five single-cross hybrids, five varieties (BRS Angela, UFVM-2 Barão de Viçosa, Viçosa, Beija-Flor, and SAM), and three commercial hybrids (Zélia, Jade and IAC-112) in five environments to examine the potential for recording in MAPA (Ministério da Agricultura, Pecuária e Abastecimento) and for possible recommendation to producers in the North and Northwest of the State of Rio de Janeiro. These authors concluded that the UENF-14 population showed promise for the regions evaluated and outperformed the hybrid IAC-112, in particular with respect to GY. This stems from the ongoing selection for 14 years of the progeny from the UENF-14 population in successive cycles of recurrent selection in the North Fluminense Region and Northwest Fluminense Region (Pereira and Amaral Júnior, 2001; Daros et al., 2002, 2004; Santos et al., 2007; Freitas Júnior et al., 2009a; Rangel et al., 2011; Ribeiro et al., 2012).

However, the recombination of progeny selected from cycle $\mathrm{C}_{6}$ of UENF-14 will help provide the most productive cultivar with the highest $\mathrm{PE}$ to farmers and consumers in the North Fluminense Region and Northwest Fluminense Region. In addition, this creates new opportunities for surpassing current estimates for GY and PE in the most advanced cycles of the UENF recurrent selection program.

\section{REFERENCES}

Agrianual (2012). Anuário da Agricultura Brasileira. Editora Argos, São Paulo.

Amaral Júnior AT, Freitas Júnior SP, Rangel RM, Pena GF, et al. (2010). Improvement of a popcorn population using 
selection indexes from a fourth cycle of recurrent selection program carried out in two different environments. Genet. Mol. Res. 9: 340-370.

Arnhold E and Viana JMS (2007). Eficiência da seleção dentro de famílias S4 de milho-pipoca, visando à obtenção de linhagens. Rev. Ceres 54: 107-111.

Cruz CD (2006). Programa Genes: Biometria. Editora UFV, Viçosa.

Cruz CD and Carneiro PCS (2006). Modelos Biométricos Aplicados ao Melhoramento Genético. Editora UFV, Viçosa.

Cruz CD, Regazzi AJ and Carneiro PCS (2012). Modelos Biométricos Aplicados ao Melhoramento Genético. Editora UFV, Viçosa.

Daros M, Amaral AT Jr and Pereira MG (2002). Genetic gain for grain yield and popping expansion in flull-sib recurrent selection in popcorn. Crop Breed. Appl. Biotechnol. 2: 339-344.

Daros M, Amaral AT Jr, Pereira MG and Santos FS (2004). Correlações entre caracteres agronômicos em dois ciclos de seleção recorrente em milho-pipoca. Ciência Rural 34: 1389-1394.

Freitas Júnior SP, Amaral AT Jr, Rangel RM and Viana AP (2009a). Genetic gains in popcorn by full-sib recurrent selection. Crop Breed. Appl. Biotechnol. 9: 1-7.

Freitas Júnior SP, Amaral AT Jr, Rangel RM and Viana AP (2009b). Predição de ganhos genéticos na população de milhopipoca UNB-2U sob seleção recorrente utilizando-se diferentes índices de seleção. Semina 30: 803-814.

Hallauer AR and Carena MJ (2009). Maize Breeding. In: Handbook of Plant Breeding: Cereals (Carena MJ, ed.). Springer, New York, 3-98.

Hallauer AR, Miranda Filho JB and Carena MJ (2010). Quantitative Genetics in Maize Breeding. Springer, New York.

Moterle LM, Lucca BA, Scapim CA and Pinto RJB (2011). Combining ability of popcorn lines for seed quality and agronomic traits. Euphytica 185: 337-347.

Mulamba NN and Mock JJ (1978). Improvement of yield potential of the Eto Blanco maize (Zea mays L.) population by breeding for plant traits. Egypt. J. Genet. Cytol. 7: 40-51.

Pena GF, do Amaral AT Jr, Goncalves LS, Candido LS, et al. (2012). Stability and adaptability of popcorn genotypes in the State of Rio de Janeiro, Brazil. Genet. Mol. Res. 11: 3042-3050.

Pereira MG and Amaral AT Jr (2001). Estimation of genetic components in popcorn based on the nested design. Crop Breed. Appl. Biotechnol. 1: 3-10.

Rangel RM, Amaral AT Jr, Scapim CA, Freitas SP Jr, et al. (2008). Genetic parameters in parents and hybrids of circulant diallel in popcorn. Genet. Mol. Res. 7: 1020-1030.

Rangel RM, Amaral AT Jr, Gonçalves LSA and Freitas SP Jr (2011). Análise biométrica de ganhos por seleção em população de milho-pipoca de quinto ciclo de seleção recorrente. Rev. Ciênc. Agron. 42: 473-481.

Ribeiro RM, do Amaral Júnior AT, Goncalves LS, Candido LS, et al. (2012). Genetic progress in the UNB-2U population of popcorn under recurrent selection in Rio de Janeiro, Brazil. Genet. Mol. Res. 11: 1417-1423.

Santos FS, Amaral AT Jr, Freitas Júnior SP and Rangel RM (2007). Predição de ganhos genéticos por índices de seleção na população de milho-pipoca UNB-2U sob seleção recorrente. Bragantia 66: 389-396.

Santos FS, Amaral AT Jr, Freitas Júnior SP and Rangel RM (2008). Genetic gain prediction of the third recurrent selection cycle in a popcorn population. Acta Sci. Agron. 30: 651-655.

Silva TRC, Amaral AT Jr, Gonçalves LSA and Candido LS (2013). Agronomic performance of popcorn genotypes in Northern and Northwestern Rio de Janeiro State. Acta Sci. Agron. 35: 57-63.

Vitorazzi C, Amaral AT Jr, Gonçalves LSA, Candido LS, et al. (2013). Selecting pre-cultivars of popcorn maize based on nonparametric indices. Rev. Ciênc. Agron. 44: 356-362. 